\title{
[Artigo retratado] Considerações sobre a importação de abelhas rainhas Apis mellifera Linnaeus, 1758 (Hymenoptera: Apidae) originadas do Mercosul
}

\section{Yago Magalhães Fontes}

Faculdade de Tecnologia de Praia Grande. Centro Estadual de Educação Tecnológica Paula Souza. Tecnologia em Comércio Exterior. Praca 1 de neiro, 144. Bairro Boqueirão. Praia Grande-SP, Brasil (CEP 1170 10 ?). -mail: yago251715mgf@gmail.com.

Resumo. Por conta dos diversos casos de mortes de abelha ocorridos em 2019, este documento foi realizado prevend uma possível procura pelo serviço de importação de abelhas rain s, processo esse que, não é realizado há mais de 10 anos de comércio exterior brasileiro. Este artigo possui com p no al objetivo demonstrar e detalhar passo a passo te t do os procedimentos burocráticos que devem ser rea ado para que a operação de importação de abelhas rainhas ypis mellifera Linnaeus, 1758 (Hymenoptera: Apidae) e tre o Brasil e países membros do Mercado Comum do Sul (N - NO UL) ocorra de forma juridicamente adequada. Consiç rando que, a importação de abelhas rainhas possa ser uma atrativa esposta aos incidentes de mortes de abelhas por co de agrotóxicos, este estudo demonstra a complexidade da ppera ão e sua viabilidade para tal cenário. A metodologia li la como base a legislação vigente, documentos xigín is no processo de importação utilizados tanto no B as qua tu nos demais países membros do MERCOSUL e site spe Alizado na área de comércio exterior.

Palavras-chav Impơração; Abelhas; Legislação; Burocracia.

Abstrac C Astions on the import of queen bees Apis
mellifera innaeus, 1758 (Hymenoptera: Apidae) originating from Mer sur. Due to the several cases of bee deaths that occurred in 2019, this study was carried out predicting a possible search for the queen bee import process, a process that has not been carried out for more than 10 years by the Brazilian foreign trade sector. This article has as main objective to demonstrate and detail step by step of all the bureaucratic procedures that must be carried out so that the operation of importing queen bees Apis mellifera Linnaeus, 1758 (Hymenoptera: Apidae) between Brazil and Mercosur member countries can happen in a legally appropriate way. Considering that the importation of queen bees can be an attractive response to incidents of bee deaths due to pesticides, this study demonstrates the complexity of the

Recebido

$04 / 05 / 2020$

Aceito

$29 / 08 / 2020$

Publicado

$31 / 08 / 2020$

Retratado

$31 / 03 / 2021$

Acesso aberto

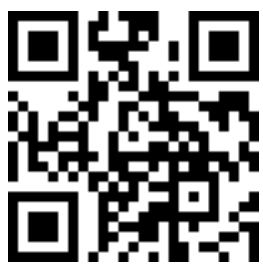

ORCID

(1) 0000-0001-8151-9880 Yago Magalhães Fontes

ISSN 2359-1412/RBGAS-2020-00072/2020/7/16/34/1011

Rev. Bras. Gest. Amb. Sustent.

http://revista.ecogestaobrasil.net 